
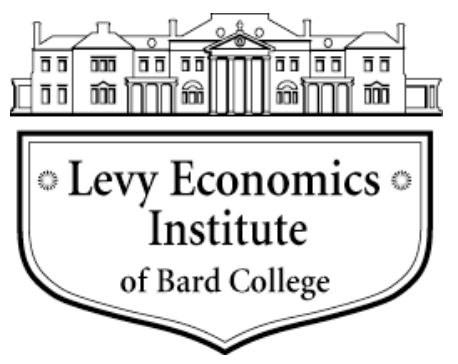

Working Paper No. 695

\title{
Orthodox versus Heterodox (Minskyan) Perspectives of Financial Crises: Explosion in the 1990s versus Implosion in the $2000 \mathrm{~s}$
}

by

Jesús Muñoz*

November 2011

*Ph.D. in economics, Lancaster University; independent researcher, Mexico City. Comments: jesusmunoz_ban@yahoo.com.

The Levy Economics Institute Working Paper Collection presents research in progress by Levy Institute scholars and conference participants. The purpose of the series is to disseminate ideas to and elicit comments from academics and professionals.

Levy Economics Institute of Bard College, founded in 1986, is a nonprofit, nonpartisan, independently funded research organization devoted to public service. Through scholarship and economic research it generates viable, effective public policy responses to important economic problems that profoundly affect the quality of life in the United States and abroad.

Levy Economics Institute P.O. Box 5000

Annandale-on-Hudson, NY 12504-5000

http://www.levyinstitute.org 


\begin{abstract}
Orthodox and heterodox theories of financial crises are hereby compared from a theoretical viewpoint, with emphasis on their genesis. The former view (represented by the fourthgeneration models of Paul Krugman) reflects the neoclassical vision whereby turbulence is an exception; the latter insight (represented by the theories of Hyman P. Minsky) validates and extends John Maynard Keynes's vision, since it is related to a modern financial world. The result of this theoretical exercise is that Minsky's vision represents a superior explanation of financial crises and current events in financial systems because it considers the causes of financial crises as endogenous to the system. Crucial facts in relevant financial crises are mentioned in section 1, as an introduction; the orthodox models of financial crises are described in section 2; the heterodox models of financial crises are outlined in section 3; the main similarities and differences between orthodox and heterodox models of financial crises are identified in section 4; and conclusions based on the information provided by the previous section are outlined in section 5. References are listed at the end of the paper.
\end{abstract}

Keywords: John Maynard Keynes; Hyman P. Minsky; Paul Krugman; Financial Crises; Financial Fragility; Asset Bubbles; Speculation

JEL Classifications: B00, B20, B30, B50, E0, E12, E13, E60, F0, F3, F4 


\section{INTRODUCTION}

Modern (bond market) financial crises started in Mexico in late 1994, followed by those in East Asia (1997), Russia (1998), Argentina (2000), and Turkey (2001). Initially these were currency crises in which the pegged exchange rate regime had encouraged lending and the generation of asset bubbles, which then unearthed deeper asset market instability and was translated into reductions in investment and hence into problems in the real sector. The exchange rate was considered as the key financial asset (speculative vehicle), since it is the thermometer of emerging economies.

Explanations of increasing content entered into the academic circles. The so called first-generation models (Krugman, 1979) and second-generation models (Obstfeld, 1994) of financial crisis were created to explain the causes, consequences, and remedies of this type of crisis.

More specifically, first-generation models as described by Krugman (1979) explain crises as the product of budget deficits triggered by the movement in a fundamental macroeconomic variable. It is the need for seignorage to cover deficits which ensures a currency collapse generated (and aggravated) by a speculative attack on foreign reserves bringing on deflationary processes. One of the distribution channels is the balance of payments.

Second-generation models (exemplified by Obstfeld 1994) explain crises as the result of a conflict between a fixed rate of exchange and the desire to conduct an expansionary monetary policy. An example of this kind of crisis is the turbulence suffered by the European Union in 1992, where finally strong economies benefitted (the United Kingdom), but relatively underdeveloped economies suffered (Spain or Italy).

Nevertheless, some of these models were subsequently considered as ad-hoc explanations on previously known facts. Subsequent crises in the late 1990s and the early 2000s (see Table 1) required a sounder explanation and hence new models of financial crises arose. In the crises in the late 1990s, the twin (and simultaneous) triggering factors were both exchange regimes and fragile banking systems. Underdeveloped economies suffered from either the "original sin" (arising from underdeveloped systems) or the impact of "moral hazard" (implicit rescue guarantees; Krugman 1999) on the exchange rate. 
In third-generation models (created by Kaminsky and Reinhart; 1996) it is argued that the core of the problem lies in the banking system. Moral hazard-driven lending provides a hidden subsidy to investment, which collapses when the government withdraws their implicit guarantees. At the end it is difficult to distinguish whether the exchange market or the banking system is the culprit of the crisis, but it is eventually translated into developments in the real sector.

Fourth-generation models (described in Tornell 2004; Dornbusch 2001; especially in Krugman 1999, who asks for a more sophisticated third-generation model; and in Caballero 2006) emphasize the roles of companies' balance sheets and capital flows in economies which are affected by abrupt variations in the real exchange rate. Private debt plays a basic role in the aftermath of crises.

Table 1 Financial Crises throughout the World (Currency Crises)

\begin{tabular}{|l|l|l|}
\hline Country/region & Year & $\begin{array}{l}\text { GDP (\%), } \\
\text { subsequent } \\
\text { year }\end{array}$ \\
\hline Western Europe & $1992 / 1993$ & \\
\hline Mexico & 1994 & -6.2 \\
\hline East Asia & 1997 & $-7.5^{*}$ \\
\hline Russia & 1998 & \\
\hline Brazil & 1999 & \\
\hline Turkey & 2000 & \\
\hline Argentina & 2001 & \\
*In Indonesia & & \\
\hline
\end{tabular}

Source: Author's elaboration

The implication is that private debt has become central to the genesis and remedy of crises in these models, which also include public debt as the original cause of crises as it eventually affects private claims. The fourth-generation models, one of the subject matters of this paper are described in detail in the next section, especially those of Krugman 1999 and Caballero 2006. 


\section{ORTHODOX MODELS OF FINANCIAL CRISES}

Emerging economies experienced swings during the mid-1990s (cf. Table 1). This is due to capital inflows that brought about constrained credit and hence a loss of control in financial domestic variables. In the beginning the study of crises was influenced by the know-how of advanced economies although crises occurred in the developing world.

A further clarification was then needed. According to Calvo (2005), financial crisis theory concerning emerging markets progressed from focusing on such variables as fiscal deficits and real currency devaluation to stressing the function of financial assets flows as well as the role of credibility. On his part, Dornbusch (2001) expressed analogous concepts.

Since the 1980s both globalization and concomitant, disordered increases in flows of capital led to high volatility in international financial markets. Some of these markets erupted into crises, in the form of runs on banks as well as attacks on currencies. More

recently, these triggering effects have extended into the realms of real estate and gold, or any other sound financial instruments.

In this type of view, the typical mobile (speculative vehicle) is capital inflows and outflows with risks and returns, and the symptom is bubbles. The creation - and use - of financial instruments must keep pace with economic growth, that is, expectations must be validated. If it is not the case, the result is macroeconomic distress and microeconomic effects (with their consequent aftermaths, policy implications, and remedies). Effects have included a significant increase in contagion and the collapse of both private banks and national institutions.

Models should include causes, interrelations, and consequences in their explanation. In the case of dynamic models, triggering factors are also essential to comprehend the internal process involved. In orthodox models of financial crises the triggering factor is a financial asset that unearths the problems of the financial sector affecting the real sector and generating a crisis, through the impact of perceptions and the ensuing speculation. This state of affairs is eventually aggravated by pessimism and ineffective remedies.

More recently, these models connect investment and debt since debt destroys the balance sheets of both real and financial firms (in both assets' and liabilities' main constituents), ultimately affecting output and confidence, thereby impacting certain industries and propitiating interest rates hikes. The triggering factor may be any financial 
asset and the behavior of assets holders, not only external debt (as in the 1982 crisis in Mexico) or the exchange rate (as in the 1994 crisis in Mexico). A highly relevant example of these models is now examined.

\section{The Neo-classical-Krugman Orthodox Model: The Fourth Generation Models of Financial (Currency) Crises}

This section synthesizes the argument exposed in Krugman 1999 which is also described in the Appendix. This type of model considers the role of money in a more in-depth (although partial and exogenous) manner. Investment is at the nucleus of this type of explanation as it is the engine of the system. According to Krugman 1999, neither first-generation nor secondgeneration models make clear subsequent developments in terms of financial crises. As Krugman states:

In the major crisis countries of Asia, however, neither of these stories seems to have much relevance. By conventional fiscal measures the governments of the afflicted economies were in quite good shape at the beginning of 1997 (Krugman 1999, p.1). Clearly something else was at work; we badly need a "third-generation" crisis model (Krugman 1999, p.1).

Most of the recent attempts to produce such a model have argued that the core of the problem lies in the banking system. McKinnon (1996) and others, myself included (Krugman 1998), have suggested that moral-hazard-driven lending could have provided a sort of hidden subsidy to investment, which collapsed when visible losses led governments to withdraw their implicit guarantees (Krugman 1999, p.1).

Following Krugman 1999, a bank-centered explanation of crises was partially correct. Other forces were also at work - for example, financial distress at the international level. Other major effects and triggering factors, respectively, are companies' balance sheets in response to reductions in investment and capital flows affecting both expectations and real exchange rates. This is related to policy implications and remedies of crises.

Krugman's model aims to clarify the role of balance sheet problems in restricting productive investment and the impact of the exchange rate on those balance sheets. Then he shows how these developments generate a vicious circle that can cause an economy to go through a financial crisis. Then he analyzes the IMF strategy of mitigating currency 
depreciation in order to protect against this balance-sheet effect, and shows how this remedy may simply engender an alternative kind of vicious circle.

Krugman states that the worsening of balance sheets played a significant role in the crisis. In addition, recovery seems to be difficult because of the weakened financial situation of firms, whose capital has in many crises been wiped out by the combination of declining demand, high interest rates, and a depreciated currency. These balance sheet problems bring about the problem of nonperforming banking loans, rather than being a banking problem.

In order to reverse the worsening of its current account, the country must undertake a large depreciation, which deteriorates the liabilities of local firms. Hence the exchange rate crisis has a sustained impact on the economy. The point is that the economy has to repair the balance sheets. Banks do not necessarily play an essential role. Banks experience balance sheet effects but respond restraining credit and hence investment.

\section{Krugman's Model}

The production function is assumed Cobb-Douglas:

$\mathrm{y}_{\mathrm{t}}=\mathrm{K}_{\mathrm{t}}^{\alpha} \mathrm{L}_{\mathrm{t}}^{1-\alpha}$

Entrepreneurs undertake domestic investment (creating capital and increasing $y_{t}$ ). Thus investment plays a decisive function.

By assumption a share $\mu$ of both consumption and investment spending corresponds to imports, whereas $1-\mu$ corresponds to domestic goods. The rest of the world is assumed to be larger than the local economy, and to spend a negligible fraction of its income on domestic goods. If the foreign elasticity of substitution is also 1, the value of local exports in terms of foreign goods is fixed at $X$. Therefore the value of domestic goods is $p X$, where $p$ is the real exchange rate.

If the share of domestic income accrued to workers spending is $1-\alpha$, then:

$y=(1-\mu) I+(1-\mu) C+p X=(1-\mu) I+(1-\alpha)(1-\mu) y+p X$

If $I$ and $C$ are, respectively, investment and consumption of domestic goods, the real exchange rate is as follows. Equilibrium in the market for domestic goods requires that:

$\mathrm{p}_{\mathrm{t}}=\mathrm{y}_{\mathrm{t}}[1-(1-\alpha)(1-\mu)]-(1-\mu) \mathrm{I}_{\mathrm{t}} / \mathrm{X}$ 
This implies that:

$\mathrm{I}_{\mathrm{t}} \leq(1+\lambda) \mathrm{W}_{\mathrm{t}}$

This is a binding constraint. The higher is investment in the local economy, the lower is its real exchange rate. Investment is the basic variable as in Keynes's analysis and may be constrained by entrepreneurs' wealth. What happens is that under diminished expectations, lenders may restrain leverage, which means that entrepreneurs can only borrow at most $\lambda$ times their initial wealth.

By assumption, the existence of the constraint implies that $p^{-\mu}$ may be taken as a constant. This means that entrepreneurs may not borrow up to the upper limit, that is, beyond the point at which the real yield on local investment equals that on foreign investment. For comprehending this point, it is necessary to compare the foreign real interest rate, $r^{*}$, with the return obtained by converting foreign goods into domestic. This requires transforming the next-period return back into:

$1+r_{t}=G_{k}\left(I_{t-1} p^{-\mu}, L\right)$

Nevertheless, a unit of foreign goods can be converted into $p_{t}$ units of domestic goods this period and the return can be converted into $1 / p_{t+1}$ units in the next period. Therefore, the statement that the return on domestic investment must be at least as large as that on foreign bonds is expressed as:

$\left(1+r_{t}\right)\left(p_{t} / p_{t+1}\right) \geq 1+r^{*}$

Moreover, as:

$\mathrm{I}_{\mathrm{t}} \geq 0$

According to the circumstances, (4), (6), or (7) may be the constraint. What is entrepreneurs' wealth? Entrepreneurs own all domestic capital, but they may also own other foreign claims and/or have debts to foreigners. By assumption some claims are denominated in terms of the domestic good, but others are denominated in terms of the foreign good. If capital lasts only one period, the value of local capital equals the income accruing to capital within the current period.

If $D$ and $F$ are the net debts of domestic entrepreneurs indexed to domestic and foreign goods respectively, this will be domestic currency and foreign currency debt respectively, 
although they are actually denominated in goods. In this case the current wealth of entrepreneurs is:

$\mathrm{W}_{\mathrm{t}}=\alpha \mathrm{y}-\mathrm{D}-\mathrm{pF}$

This equation can be used to inspect how a financial crisis can occur in an open economy.

\section{The Transfer Problem and Financial Crisis}

The wealth of each entrepreneur depends on the level of his (her) borrowing in the whole economy, because the volume of capital inflows affects both the terms of trade and the valuation of foreign currency-denominated debt. Therefore a decline in capital inflows can adversely impact the local balance sheets, reducing entrepreneurs' borrowing.

Credit supply may depend on lenders' expectations about the value of the borrower's collateral. But because some debt is foreign-denominated, this value depends on the real exchange rate and hence on the actual level of borrowing taking place. This process seems to tend to a neo-classical-type of equilibrium related to a set of self-confirming guesses.

If, ceteris paribus, wealth depends on $p$ and it is clear from (3) that $I$ determines $p$. If $I_{f}$ is the "financeable" level of investment, that is, the level of investment that would occur if the leverage constraint (4) were binding, entrepreneurs' borrowing depends on their wealth, then:

$\mathrm{dW} / \mathrm{dI}=(1-\mu) \mathrm{F} / \mathrm{X}$

$\mathrm{dI}_{\mathrm{f}} / \mathrm{dI}=(1+\mu)(1-\mu) \mathrm{F} / \mathrm{X}$

If $d I_{f} / d I>1$ there can be multiple equilibria. The possibility exists that a loss of lender confidence will be validated by a financial crash. More specifically, if local-currency debt is high, entrepreneurs may be unable to borrow even with a favorable exchange rate, and depression may arise.

At high levels of $I^{e},(4)$ is irrelevant. Instead, investment is determined by the rate-ofreturn constraint (6). Conversely, at low levels of expected $I$ firms are bankrupt. The constraint (7) is too strong for them.

At the intermediate level $I$ is constrained by financing. The intermediate equilibrium is unstable under any expectation formation. There are two other possible outcomes. The first one is a high-level outcome $H$ in which investment may be taken up to the point where 
the local foreign rate of returns equals the foreign rate of return. There may also be a lowlevel result $I$ in which lenders do not believe that local entrepreneurs may have any guarantee. In this case their failure to provide funds is the consequence of a depreciated currency implying that entrepreneurs are bankrupt.

For example, in the 1997 financial crisis (cf. Table 1) there was a collapse from $H$ to $L$, which did not mean that the previous investments were weak, but only that there was financial fragility because of high debt. In this model, the factors that make financial collapse possible are low marginal propensity to import and large foreign-currency debt relative to exports but especially high leverage.

These factors make the circle - from investment to real exchange rate to balance sheets to investment - more influential. The message is that high leverage matters. Only after 1990 (globalization), emerging economies began extensive foreign-denominated borrowing and crises ensued. Foreign borrowing placed them at risk of financial collapse.

\section{The Dilemma of Stabilization}

Former models of currency crisis are silent about the problems posed by foreign-currency debt, but this is the major consequence of financial crises. And the risks of that debt were why the prescription for defending currencies was interest rates hikes in order to both halting capital outflows and attracting capital inflows. The upshot was to hold the real exchange rate $p$ constant even when the willingness of foreign lenders to finance investment was reduced. As something else must have been given, the common assumption is that economic activity declines.

If that is the case and if $p$ is held constant, $y$ will be determined by a kind of Keynesian-Kahnian multiplier process. If (2) is rearranged:

$\mathrm{y}=\mathrm{pX}+(1-\mu) \mathrm{I} / 1-(1-\alpha)(1-\mu)$

But a share $\alpha$ of output goes to profits, thus a reduction in investment will diminish entrepreneurs' wealth:

$\mathrm{dW} / \mathrm{dI}=\alpha(1-\mu) / 1-(1-\alpha)(1-\mu)$

The feedback from actual to financeable investment is:

$\mathrm{dI}_{\mathrm{f}} / \mathrm{dI}=(1+\alpha) \alpha(1-\mu) / 1-(1-\alpha)(1-\mu)$ 
According to Krugman 1999, stabilizing the currency closes one channel for potential financial collapse. Nevertheless, it opens another. If leverage is high, the economy may stabilize its real exchange rate only at the price of a self-reinforcing decline in economic activity (cf. Appendix). This is why only emerging economies suffer from crises as they possess weak balance sheets (the "original sin").

In terms of causes, something external, according to Krugman (1999), provoked the crisis. Thus, whereas Krugman acknowledges the roles of both investment and debt during the unfolding of the crisis, his model is silent about the internal nature of the crisis, except that it started in the real sector (in terms of entrepreneurial wealth).

Thus, these models pay no attention to the fact that productive investment (and the twin processes of assets allocation and financial investment) is endogenously determined in the financial sector. This is a key message of Keynes with respect to the performance of modern economies.

\section{Policy Implications of Krugman's and Similar Models}

Only emerging economies are prone to financial and entrepreneurial vulnerability through balance sheet problems. As triggering factors are external and then crises take the form of isolated episodes, policy implications are the use of prophylactic (nonessential, ex post) measures such as interest rate hikes, capital controls, ex post regulation, and the provision of emergency credit lines.

Nevertheless, orthodox models are silent about deep (and preventive) financial structural reforms, except by the construction of a new financial architecture (Frankel 2003), bank restructuring, risk management, and bank capitalization (Basel III 2011), treating these measures however as if causes of crises would refer to exogenous (exceptional) factors, even taking these remedies as if the problem is miscalculations in risk management.

In other orthodox models (cf. Tornell, Westermann, and Martínez 2004), the causality and its corresponding policy implications are very similar. For them since the 1980s a process of liberalization, especially in financial systems, was initiated and accelerated throughout the world. This has been a long-term process that has brought about reforms enhancing growth and has made stronger economies, especially in the emerging world. Once again crises are isolated (corrective) episodes, or the price to be paid for liberalizations. 
Since crises are not inherent to capitalist economies, they do not impede long-term growth. The corresponding policy implication is that more liberalization (and hence less regulation) is required with industrial misallocations (at both the domestic and the international levels) being the price to be paid. This is a kind of Darwinian argument whereby many enterprises or industries fail during the process.

\section{Similar Orthodox Explanations of Financial Crises: Shortage of Assets}

Economies are vulnerable due to either moral hazard or the "original sin." The former refers to abuse in private and public debt before a lender of last resort, whereas the latter states that underdeveloped economies are highly prone to experience crises due to weak industrial and financial structures and that the remedy is growth and privatizations, that is, more market orientation is needed in underdeveloped economies. Other orthodox insights are related to mismatches between short-term debt and long-term debt.

From a more holistic perspective, Caballero (2006) talks about the macroeconomics of assets shortages. The shortage of financial assets throughout the world is at the core of his explanation. He treats this issue as the cause, instead of the symptom, of problems in unstable economies.

For Caballero (2006) there are many assets demanders and few assets producers. As assets production requires financial restructuring, financial innovation, and growth, the critical point is the response of assets prices and valuations to shortages. Scarcity generates global imbalances and speculative bubbles - for example, those in emerging economies. Shortages are seen as temporary insufficiency in international liquidity due to low interest rates, low inflations, and deflation episodes.

In this view emerging markets have contributed to the current worldwide shortage of assets. Firms and individuals borrow for catching up and for smoothing inter-temporary consumption (a neo-classical insight). In general terms assets shortages are due to three types of deficiencies: micro, macro, and political. In synthesis, local assets have low value and safety and agents search for international assets.

Speculative bubbles are based on the short-term returns of assets (capital gains) rather than on dividends which entails dynamic inefficiency, but at the end equilibrium is achieved. Speculative booms do not imply fragility. In recent times both real state and 
corporate assets are the focus of attention, but at the beginning appreciation fueled appreciations.

Investors' moods cause an implosion in local asset values as they bring about scarcity in international liquidity. If yields increase, the value of the collateral also rises. This implies that risks increase, which requires ex post intervention in isolated episodes. This is due to shocks being accidents and money or financial assets do not play the main role in the story.

An implication is that developed economies differ from emerging economies as the former are assets producers. In the event of a crash, developed economies are more resilient since they are able to absorb imbalances on the availability of assets. The corollary is that only excessive risk-taking and shortages of good assets require intervention on the part of central banks. State-of-the art regulation is able to contain shocks.

On the other hand, the conduction of monetary policy (by modifying inflation targets by means of rules) improves risk management processes. This line of thought does not address the problem of deprivation of credit; the long-term solution of crises is financial development, as sound assets crowd out bubbles (cf. Caballero 2006).

Nevertheless, globalization spreads assets shortages into the world at large. Hence, the crises are not exclusive of emerging economies. Global imbalances exist neglecting the fact that the anglo-saxons supply assets. This only means that assets flows are uneven. The relevant point is that assets shortages are due to interest rate decreases, which explains why speculative episodes are occasional.

In this type of explanation, speculative bubbles are, along with inflation reductions, just market mechanisms for bridging gaps in assets. Bubbles must exist: If yields are diminished then bubbles arise (cf. Caballero 2006) and spread across the whole economy.

Are there escape valves in the economy? The cost is a deflation with a Phillips Curve, and the economy waits for the Pigou Mechanism to restore lost assets, although the Pigou Effect only operates under certain conditions according to Minsky.

This orthodox model, however, recognizes that crashes are more abrupt than booms, but not that booms generate busts. Once again, crashes are due to strange shocks and misguided policies. Whereas low interest rates have caused the problem, this is considered as an exogenous development. Somehow interest rates are low at a certain moment so that forces are external to the model. 
Agents face Knightian uncertainty, in the sense that they can manage risks within certain boundaries. Unlike in Monetarism, no mechanic rules must exist. All intermediaries maximize values and free collaterals and atomism (the Village-Fair Paradigm) is implicitly assumed. Yet financial intermediaries understand their risks but are uncertain about others.

In synthesis, assets shortages are the source of instability (rather than either uncertainty or investment in the sense of Keynes). These types of shortages produce global imbalances, deflations (not debt deflations), recurrent bubbles, and financial panic. Bubbles and their remedies are explained in the model of Caballero (2006) by means of a mathematic model with equilibrium at its center.

Assets shortages are by the way the source of recent macroeconomic developments since the 1990s. As causes of financial crashes are not deep or systematic in these models, the prescription is that financial systems must grow in qualitative terms throughout the world. Nevertheless, this explanation neglects that many historians of economic thought, as well as many economists, had advanced explanations of financial crises since the $1950 \mathrm{~s}$.

If bubbles are a necessary condition for attaining equilibrium however, this is a similar argument to that expressed by Friedman in the sense that speculation is stabilizing (Friedman 1966). This is not surprising, as the hard core of Monetarists is the same as that of the neo-classical economists, both neglecting Keynes's message about uncertainty and the nonexistence of a self-regulatory mechanism on the part of the system.

\section{Policy Implications in the Event of Assets Shortages}

Assets shortages imply optimal policy responses whereby risk management is necessary as a remedy rather than prevention as appropriate risk management implies high-valuation equilibria. Orthodox economists, at least in the models described above, believe in equilibrium, rationality, and the nonexistence of structural weaknesses in the system. These weaknesses are normally corrected by means of market measures.

Equilibrium will eventually be reached as bubbles only exist in a high-valuations environment. The point is that returns and hence assets valuations must not exceed economic growth. That is, crises are exogenous.

Financial development must increase assets supply and reduce the demand for assets. If speculative valuations are part of equilibria the implication is to minimize resource misallocations. 
Policy makers must strengthen both collateral positions and risk management shifting and reduce the conditions for the arising of "moral hazard" (actually a Krugman's intuition). Since the use of collaterals increases the efficiency of the financial system, the role of the lender of last resort must be at best corrective in certain instances. This leaves them wondering why macroeconomists are needed.

The classical orthodox solution is to reduce interest rates to increase economic activity and to avoid speculation in the relevant asset. However, these variables represent the symptoms (or the effects) of crises. They are not the cause. The actual remedy should be preventive banking with an eye on uncertainty and potential entrepreneurial problems. This is the main message of the model outlined in the next section.

\section{HETERODOX MODELS OF FINANCIAL CRISES: THE MINSKY MODEL}

Orthodox models were constructed for explaining the financial crises in the 1990s. The crisis of Mexico in 1994 was produced by a combination of over-lending (which was accelerated since 1992) with an exchange-rate peg (which started in 1987). Nevertheless, in terms of the genesis of the crisis, Mexico certainly suffered from financial fragility (in terms of debt).

The next task is, thus, resorting to the message of Minsky in the explanation of the unfolding of financial crises. The outline of Minsky's theory follows the expositions of some postKeynesians mentioned in the references.

\section{Keynes's Influence on the Minskyan Model}

Keynes demonstrated that money is not a veil in terms of the impact of its variations on the real sector, specifically through investment. He was also interested in the theory of liquidity preference (linked indirectly to investment). Hence, he developed a superior conception of the financial sector.

Minsky followed the message of Keynes to the extreme of considering that the financial sector, both in terms of assets and liabilities, was at the heart of the unfolding of crises in terms of causes, motives, interrelations, and consequences, wherein booms generate busts. This consideration made his model endogenous. Given that money is the main component of the system, it has an impact on the real sector and ignites financial crises.

The core of Minsky's model is the Financial Instability Hypothesis (FIH) with both investment and debt at its center. Minsky sees a modern financial system, which has 
feedback with the real sector. But this relationship between the financial and the real sectors can be adverse due to the possibility of the existence of instability. FIH can be de described as follows.

\section{The Financial Instability Hypothesis}

Minsky advanced theories for explaining financial market fragility and its consequences since the 1970s (Minsky 1974, 1982a, 1986, 1993). Bubbles endogenously arise from developments in financial markets. In booms corporate cash flows rise beyond debt. However, immediately after, debts exceed borrowers' payments. At the same time agents feeling free of commitments develop speculation, lenders tighten credit, and investment and production contract. This is known as the "Minsky moment". Booms generate busts amid asset bubbles.

Minsky had experience as a practitioner and also had a historical (rather than a logical ${ }^{2}$ ) view. Furthermore, he also considered the deregulation processes of the 1980s as primary causes of crises. In his view financial innovation and diversification (along with fraud and "cooperation" between private and public sectors) all paved the way for the crises in the 1990s. This is also outlined in recent post-Minskyan heterodox views of financial crises (cf. Wray 2009).

Following Keynes, Minsky's theories emphasize the macroeconomic dangers of speculative bubbles in asset prices (for instance, in an exchange rate) as well as the notion of uncertainty. This is at odds with the mainstream view, which considers speculation as selfstabilizing with only microeconomic (and short-term) effects. In addition, money plays a minor role on the functioning of economies in the neo-classical view, where both certainty and perfect information play a pivotal role.

In Minsky's view, the internal mechanism pushing an economy toward a crisis is the accumulation of private debt. This is related to both assets allocation and investment and to cash flows. In his well-known taxonomy, Minsky distinguishes three types of borrowers, which contribute to the accumulation of - eventually — insolvent debt. They are hedge, speculative, and Ponzi.

If the use of Ponzi finance (which is either unwise in terms of timing or fraudulent perhaps based on inside information) reaches a critical mass, then domino falls of Ponzi

\footnotetext{
${ }^{2}$ In the sense that he does not consider that the system must necessarily tend to equilibrium.
} 
borrowers can cause the system to implode when the bubble pops - for example, when asset prices stop increasing due to news or supply shocks. As a consequence, the speculative borrower and even hedge borrowers can no longer refinance the principal. In both cases the decomposition process is accelerated by-non-borrower-speculators.

Many elements of Minsky's analysis are present in the list of orthodox models: News (Dornbusch 1980; Frenkel 1982), the Peso Problem (Rietz 1988), or Bubbles (Blanchard 1979). These are actually models of exchange rate determination, but they are the prototypemodels of financial crises. News refers to the impact on the exchange rate of the arrival of new information. The Peso Problem is an explanation of hihg-risk premia when events which were considered ex ante do not materialize in the future. It assumes rationality. Bubbles refer to the impact of overvaluation on the economy. However, these elements are analyzed in isolation, and shocks in these explanations are always abnormal.

Moreover, investors are heterogeneous. They are also at different stages and they take into account developments in the international financial sector. For these considerations, Minsky's model is very rich in terms of the genesis, with details in terms of interrelations and its emphasis on the role of financial systems in the unfolding of crises.

Minsky also furthered Keynes's notions about the interrelations between the real and financial sectors and the fact that financial markets can observe excessive movements as a norm. But Minsky gave real expression to Keynes's concept of uncertainty.

Minsky's theories about debt accumulation explain the subprime mortgage crisis of the late 2000s, whereby the initial assets targeted by speculators were housing prices. In 2007, lenders funded Ponzi borrowers. Both of them assumed that housing prices would continue to increase forever. As lenders had inside information or market power, they made abnormal gains.

The progression through Minsky's three borrowing stages simply reflected the credit and housing bubbles built throughout the crisis. Thus, the causes of the problem were endogenous. Demand for housing was both a cause and a consequence of expanding shadow banking systems, which encouraged even riskier mortgage loans. When the bubble burst the opposite progression ignited a world financial crisis due to contagion, which was fueled by perceptions. 
The economy is highly volatile because expectations are highly volatile as well. Speculation fueled by debt is based on the valuation of financial instruments. It is based on unpredictable, but objective factors. Moreover, speculation disturbs the efficiency and stability of the system, being an emerging property of the complex system. Money is the relevant variable of instability in the system through its effects on debt and investment and, thus, FIH contradicts the analysis of the neo-classical synthesis whereby the role of money is neglected.

Clearly macroeconomics exists since instability has to be addressed. For Minsky debt leads and investment responds. Investment is constrained by firms' finance rather than by moods or animal spirits. Hence, Minsky objectively identifies the source of uncertainty, a core concept of Keynes. Minsky's theories have not been incorporated into mainstream economics. Furthermore, the orthodox view precludes private debt as a cause.

\section{More Details on the Financial Instability Hypothesis (FIH)}

The idea is that stability is destabilizing in a capitalist system since processes are driven by internal financial developments. FIH is both an investment theory of the business cycle (like in Keynes) and a financial theory of investment. In that way Minsky extends Keynes's message.

Profits are the key variable for both debt validation and the valuation of capital assets. This is the theoretical reconstruction of an economy with a sophisticated financial system and with endogenous money. The analysis departs from dynamic cash flows (both income and revenues) and the interdependence among balance sheets (assets of some units and liabilities of others). Balance sheets are affected by expectations. Finance (and especially external finance) is raised on the expectation of uncertain cash flows.

Uncertainty not only affects production but also financial commitments and hence liability structures. Investment may be financed through portfolio allocations and debt, and this constrains liquidity affecting balance sheets.

All this accounts for the importance of the two-price model whereby products have a price level whereas assets have another price level, the latter being based on expectations. Leverage and debt services are not sustainable if profit levels become unacceptable. This rules out the idea of perfect competition prevailing in orthodoxy where profits tend to zero. 
Thus, fragility is not the result of an underdeveloped financial system but the normal result in capitalism. The implication is that an external shock may detonate but not cause a financial crisis. For instance, interest rate fluctuations produce instability, thereby generating financial collapses, impeding economic growth, and bringing about unemployment (which is hence not due to insufficiencies in effective demand).

The interaction between assets, investment, and production determines the endogenous and cyclical system dynamics. Endogenously refers to the fact that structures evolve from robust to fragile. Keynes's notion of liquidity preference is extended by Minsky to all financial assets and investment refers to both physical and capital assets.

Minsky's theoretical targets are the ceilings and floors that must be set by authorities. His method is the use of a piece-linear model with a historical focus. The implication is that microeconomics possesses macroeconomic foundations and uncertainty gives the analysis a dynamic character.

Minsky pays attention to the monetary circuit (M-C-M'), where $\mathrm{M}=$ money and $\mathrm{C}=$ commodities. In this view profits agents are profit-maximizers. The financial system is comprised by institutions, markets, instruments, and practices.

The core of Minsky's model is money matters, markets work out of equilibrium, and both governments and central banks play a crucial funtion. For Keynes, changes in expectations (via its effect on productive investment) detonate crises, but Minsky incorporates the analysis of debt and therefore the role of both banks and companies. Whereas Keynes is focused on cash flows, Minsky concentrated on both cash flows and debt.

If financial deregulation and innovation impinge on the endogenous development of the system, these aspects are not analyzed by those of the orthodoxy who think that crises are provoked by exogenous factors. In terms of both vision and method, organicism is a key concept in Minsky. Organicism is defined as a system in which the sum of their constituents is more than the number of those constituents, and its interrelations are neither simple nor unidirectional. This due to Minsky proposes a philosophy of endogenous change (cf. Keen 2001).

Finally, financial vulnerability is difficult to measure since mathematical modeling and nonstationary processes clash with a sequential and a historical method of analysis. In 
the latter type of analysis, the future is not a continuation of the past. Moreover, phenomena are casuistic and noneternal.

The focus must also be on the financing of investment (and of positions). For Minsky, capitalism is a complex system in the sense that it is comprised by interrelated balance sheets. Risk cannot be eliminated as it is always present. If portfolio compositions reflect uncertainty, instability comes from the assets side too.

Minsky is hence against IS-LM (Investment Saving/Liquidity preference Money supply) or Monetarist models that leave aside the concept of uncertainty and where money is neutral. Furthermore, these models are static and atomistic (in the sense that interrelations do not play a pivotal role in the evolution processes). Financial relations are highly sophisticated since an expectational term always operates in them. Minsky thus rejects the laissez faire-market efficiency-rationality paradigm with its idolatry for equilibrium. No room exists in his analysis for the Modigliani-Miller theorem.

Capitalism is not able to advance in a straight line but in waves of panics and euphoria. For Minsky, finance is the source of instability. However, Keynes set the right direction by initiating the paradigm of money relevance, uncertainty, and asset allocation in economics. He also blurred the distinction between the real and the financial sectors.

Whereas exogenous factors impact the system at the beginning, sequential endogenous factors affect the system at the end. This is related to the transit from stability to instability. Any economy with increasing private debt is highly exposed to investment fluctuations and therefore to endogenous disruptions in growth. Policies to balance cash flows are required for restoring equilibrium as can be seen in the next subsection.

\section{Policy Implications}

For Minsky, solutions are not permanent or valid in every case when addressing the problems of instability and unfairness of market economies. The main idea is that instability exists and there must be policy reactions (financial reforms) to it. The financial system requires policy intervention since its vehicle is finance.

There has been increased interest in the policy implications of Minsky's theories since the financial crisis of 2007, considering that prevention is very relevant. According to Minsky, at the end swings can be mitigated, anticipated, or controlled. The implication is the 
implementation of counter-cyclical policies. A suggestion for regulators is the need for mandatory contingent requirements of capital.

Measures must be ex ante as evolution is a dialectical process. Policies must differ from those of the orthodoxy as there is an interplay between endogenous forces and institutions as the system evolves (in terms of both financial assets and investment).

The money manager is the key figure. Profits arise from a scarcity of financing for capital goods and this has to be addressed as the valuation of capital goods and instruments affects investment.

According to Minsky, discretionary intervention from both the government (budget deficits) and the central bank (lender of last resort) mitigates instability by creating upper and lower limits for constraining the dynamics of the system. Policy targets in institutions are of the socialization of investment and restructuring of government activities. Government must undertake deficits in order to support profit levels, generate automatic stabilizers, and conduct discretionary policies, providing a continuous set of remedies rather than palliatives.

Central bank intervention refers to the stabilization of interest rates and assets prices, since budget deficits bring about higher profits which strengthen balance sheets and assets prices. Nevertheless, the central bank can only detain and counteract damages in the system. In addition, financial structures must be simplified. Finally, central banks must do monetary policy and regulate and reform the financial system (paying attention to expansion, innovation, and practices in the management of financial instruments).

In this sense, the suggestion is to move away from debt to equity financing as a permanent remedy for reducing risks arising from interest rate hikes (cf. Muñoz and Snowden 2006). But this is both an institutional problem and a problem of underdevelopment in the financial system.

The targets of speculation must be addressed as most behaviors are speculative. The problem is that the monetary transmission mechanism operates through the balance-sheet channel, especially when financial activities are not controlled and hence it affects credit. Finally, the management of the money supply affects firms' conditions given that increases in interest rates fuel debts and reduce the price of assets as well as bank lending. 
If there are swings of optimism and pessimism which pose a macroeconomic problem, the difficulty can only be attacked by implementing preventive measures with respect to the links between investment and debt. The next section outlines the differences between the orthodox and the heterodox views on financial crises.

\section{SIMILARITIES AND DIFFERENCES BETWEEN ORTHODOX AND HETERODOX MODELS OF FINANCIAL CRISES: IMPLOSION VERSUS EXPLOSION}

Similarities between orthodox and heterodox models are simple. In both cases crises start with a large and sudden decline in the price of a main financial asset, the size and fastness of this reduction reflecting the extent and severity of the crisis and the loss of credibility as well as the reach of contagion. Contagion is automatic once expectations are negative.

In both types of models, investment is the engine of both the system and business cycles, and hence emphasis must be placed on the financing of investment, debt, and balance sheets. The crises ultimately affect output and employment everywhere as well as income distribution and inflation in emerging economies (see Baldacci et al. 2002). This explanation is also about the effects of crises on ex post fiscal retrenchment.

Therefore, domestic vulnerability is relevant in both the industrial and the financial sectors. The implication is that crises require reforms in financial sectors. However, these are the only commonalities between the two sets of models, which are superficial. The orthodox models talk about domestic vulnerability, but this is external. This brings us to differences.

\section{Differences between Orthodox and Heterodox Models of Financial Crises}

Neo-classical-type models talk about what must be rather than what is, unlike heterodox models. A consequence is that differences are deeper and more interesting than commonalities. In orthodox explanations of financial crises, the system tends to equilibrium like in the neo-classical world. Moreover, in orthodox models atomism and the passivity of

money are the implicit assumptions. In contrast, endogeneity and organicism (as opposed to atomism) are two characteristics of a complex system as that described in Minsky regarding Wall Street economies. 
Atomism as advocated by village-fair economies, like in the neo-classical world, is translated into the following respects:

- Economic agents are homogeneous (the so-called homus economicus).

- Financial and industrial sectors are not linked.

- Such external factors as industrial problems, trade deficits, contagion, and supply shocks propitiate crises.

- Neither money nor uncertainty plays a decisive role in economic events.

The consequence is that orthodox explanations rely on exogenous triggering factors, just as supply shocks were introduced as an explanation of disturbances by neo-classical macroeconomists during the 1980 s.

The story is different for heterodox economists. To begin with, for Keynes there exists underemployment equilibrium, animal spirits, uncertainty, and the economy functions as a unity (organicism). As a consequence of this, the heterodox view of financial crises relies on endogenous factors in the unfolding of crises. In particular, Minsky makes uncertainty operational, wherein booms generate busts through his typology of debt. The ultimate outcome is that investment decreases and propitiates crises. This is the endogenous explanation of financial crises, which can be internally cured.

For these reasons Minsky's model is a more complete explanation of how the economy actually works rather than how it must work provided that markets operate in an efficient manner. Minsky links investment with debt (cash flows and profits with commitments) within a historical framework. Financial innovation and financial regulation not only exacerbate but cause debt problems in a system that is in permanent evolution.

The orthodox explanation is insufficient because it ignores the pivotal role of money in the unfolding of crises. Moreover, for heterodox explanations of financial crises:

- Financial institutions are the essential part of the system.

- The profit motive (and destabilizing speculation) must be considered as part of the explanation of instability. In contrast, abnormal profits do not exist in a perfectly competitive system which automatically tends to equilibrium in the neo-classical view. 
- Destabilizing speculation is a triggering factor in heterodox explanations. However, orthodox economists believe in rationality and equilibrium and hence in stabilizing speculation (cf. Friedman 1966).

- The evolution of money supply is irrelevant (or insufficient) for explaining the problem of financial crises for heterodoxy.

- Abnormal information, price rigidities, occasional deficiencies or co-ordination failures are not the cause of the problem in a complex system.

- Mismatches in assets compositions are the rule rather than the exception, although Keynes talks about a price (rate) that equilibrates the market of all assets.

- The existence of efficiency in the banking sector with only occasional deviations from rationality is a myth.

- The role of government is preventive in Minsky's model, but palliative in the orthodox models.

Some orthodox models discuss the implications of short-term profits in banks' behavior and global schemes of risk but not in terms of uncertainty. For Minsky, profits along with debts (a topic not analyzed by Keynes) lie at the core of the development of crises. The corollary is that the structure of financial agencies must be inherently reformed.

The orthodox analysis separates investment from leverage decisions. In FIH the interaction of investment and debt levels is what ultimately triggers a crisis. Whereas both Keynes and Minsky are focused on behavioral finance, orthodox models rely on equilibrium and rationality, efficient markets, and perfect information and complete knowledge following the neo-classical direction. Some versions of the orthodox models seem to be based on a book of Corporate Finance (cf. Caballero 2006).

In the study of financial crises, investment is the engine of the system and money its main emerging property. However, in the orthodox models causes are not deep and interrelations are simple as well as exogenous, atomistic, direct, and linear, precluding them from explaining the problem. The implication is that the main message of the heterodox view on financial crises is that crises retard growth. In contrast, orthodox economists consider crises as necessary in the process of liberalization. In terms of policy implications, 
any model addressing internal causes will be more successful. If prevision is undertaken, cycles will be smoother.

Finally, in terms of method Minsky's model follows a sequence of explanations in an increasing order in terms of complexity in interrelations with a historical focus, whereas for orthodox economists explanations are positive (only addressing facts) and given in mathematical terms.

\section{CONCLUSIONS}

Conclusions are implicit in the analysis undertaken in the former section, but they are extended now. There is a link between Krugman's crises models and Minsky's hedge, debt analysis. This being now acknowledged brings about a further upsurge in the literature of asymmetry and coordination failures. Nevertheless, Minsky disliked asymmetry and coordination failures, as his vision biased incentives to intermediate capital flows that are the normal condition of capitalist economies.

In the global financial crisis of 2007 with private debt and government budget deficits, monetary policy and "money manager capitalism" in the financial markets all contributed to the crisis, but the conventional wisdom is that the triggering factor was mortgages. What is the best explanation, orthodox or heterodox?

According to the former sections of this investigation, there are differences between these sets of models in terms of essence, content, reach and limitations, equilibrium, time, concept of man, and dichotomy of markets and agents. Organicism, expectations, the consideration of cash flows and debt, and the role of money are the main contributions of heterodox economists to the explanation of crises. All of these elements may be referred to as differences between Keynes and the neo-classical economists.

Based on these insights, it is hereby argued that a heterodox (deeper) analysis along Minskyan lines produces a more coherent theoretical and policy analysis of the newer and more complex financial crises. The principal difference between orthodoxy and heterodoxy (as represented by Minsky) is that fourth-generation models consider that shocks producing instability are exogenous to the system and therefore random. Moreover, orthodox models are unable to predict crises as they confuse symptoms with causes. This is a methodological weakness. 
In Minsky's FIH shocks arise from uncertainty. In this explanation taking account of timing is essential for preventing crises and this timing can be anticipated by resorting to Minsky three stages in the unfolding of debt as an actual early warning system.

On the other hand, policy prescriptions in Minsky (FIH) address structural problems in the financial sector that can be fixed by means of reforms and the provision of liquidity and solvency, considering the role of big government. In the orthodox view, the role of government is limited to solve crises.

Orthodox theories are a repetition of neo-classical theories, where disequilibrium is an anomaly and money is a veil. They have nothing relevant to say about financial crises in the sense that they derive their views on the alienation and exogeneity of money from both the Classical and the Walrasian views as well as their ignorance about historical time.

All of this arises from Keynes's concept of an inherently unstable financial system and especially from his vision on simultaneous asset equilibrium. This is in turn partially originated from Marx's vision, specifically from the identity defining the functioning of the system: M-C-M' (cf. Keen, 2001). This identity is acknowledged by Keynes (1936) and thereby by his followers. Accordingly, money has an endogenous influence on both investment and debt.

Summarizing, Minsky’s model thus links all elements of economic systems. In contrast, Krugman considers investment as exogenous to the model or determined in the real sector (cf. 1999), whereas other models consider that imbalances in capital flows are due the difference among international financial systems (cf. Caballero 2006). At the end, Krugman acknowledges the work of Minsky. If orthodox explanations are relevant for outlining the crisis in the 1990s, Minsky's insights are relevant for the time to come.

For heterodox economists, crises are inherent to both emerging and developed economies. According to orthodox economists, all domestic invulnerability, good balance sheets (Dornbusch 2001), no over-lending (McKinnon and Phil 1996) or strong assets (Caballero 2006) imply that no financial crisis will occur. But if these motives arise due to systemic causes, in Minsky's model there is a chain of causal reactions (like in Keynes's model of TGT [1936]), although the sequences vary from case to case in financial crises.

In terms of method and vision, heterodox economists depart from Keynes's legacy of uncertainty whereas orthodox economists follow neo-classical methods. It can be argued 
alternatively that heterodox economist follow either a Schumpeterian or a Marxian vision (cf. Keen 2001).

On the more positive side of the comparison, orthodox models call attention to specific issues - for example, the impact of crises on income distribution (cf. Baldacci et al. 2002). This topics is also studied by post-Keynesians. This means that both sets of models are complementary.

This paper has only dealt with the theoretical background and policy implications of the heterodox perspective on financial crises. The diffusion, reception, acceptance, and influence of this perspective are the topics for further studies. 


\section{REFERENCES}

Aghion, P., P. Bacchetta, and A. Banerjee. 1999. "A simple model of monetary policy and currency crises." Cahiers de Recherches Economiques du Dèpartement d'Economètrie et d'Economie Politique (DEEP) 9914, Université de Lausanne, Faculté des HEC, DEEP.

Baldacci, E., L. de Mello, and G. Inchauste. 2002. "Financial crises, poverty and income distribution.” IMF Working Paper No. 02/01. Washington, DC: International Monetary Fund.

Baldacci, E., S. Gupta, and A. Mati. 2008. "Is it (still) mostly fiscal? Determinants of sovereign spreads in emerging markets." IMF Working Paper No. 08/259. Washington, DC: International Monetary Fund.

Basel III. 2011. "Macroeconomic impact of Basel III.” February. doi:10.1787/5kghnhkkjs8-en, accessed on October 3, 2011. www.basel-iiiaccord.com

Bellofiore, R. and P. Ferri. 2001. "Introduction.” In R. Bellofiore and P. Ferri, eds., Financial Keynesianism and Market Instability. The Economic Legacy of Hyman Minsky, Volume I. Chentelham: Edward Elgar.

Blanchard, O. 1979. "Speculative Bubbles, Crashes and Rational Expectations." Economic Letters 3: pp. 346-65.

Caballero, R.J. 2006. "On the macroeconomics of asset shortages." MIT and NBER, the $4^{\text {th }}$ ECB Central Banking Conference on The Role of Money: Money and Monetary Policy in the Twenty-first Century. Frankfurt. November.

Calvo, G.A. 2005. Emerging Capital Markets in Turmoil. Bad Luck or Bad Policy? The MIT Press: Boston.

Calvo, G.A. and C.M. Reinhart. 2000. "Fear of floating.” NBER Working Papers 7993. Washington, DC: National Bureau of Economic Research. November.

Chick, V. 2001. “Cassandra as optimist.” In R. Bellofiore and P. Ferri, eds., Financial Keynesianism and Market Instability. The Economic Legacy of Hyman Minsky, Volume I. Chentelham: Edward Elgar.

Corsetti, G., P. Pesenti, and N. Roubini. 1998. "Paper tigers? A model of the Asian Crisis." NBER Working Papers 6783. Washington, DC: National Bureau of Economic Research.

Day, R. 2001. "Economics in the spirit of Minsky." In R. Bellofiore and P. Ferri, eds., Financial Keynesianism and Market Instability. The Economic Legacy of Hyman Minsky, Volume I. Chentelham: Edward Elgar. 
Dornbusch, R. 1980. "Exchange rate determination. Where do we stand?" Brookings Papers on Economic Activity 1: pp. 143-85.

- 2001. “A primer on emerging market crisis.” NBER Working Papers 8326. Washington, DC: National Bureau of Economic Research. June.

Dymski, G.A. 2010. "Why the subprime crisis is different: A Minskyian approach." Cambridge Journal of Economics 34 (2): pp. 239-55.

Dymski, G.A. and R. Pollin. 1993. "Hyman Minsky as hedgehog: The power of the Wall Street Paradigm.” In S. Fazzari, ed., Financial Conditions and Macroeconomic Performance. Armonk, NY: Sharpe.

Edwards, S. and M.A. Savastano. 1998. "The morning after: The Mexican Peso in the aftermath of the 1994 currency crisis." NBER Working Paper 6516. Washington, DC: National Bureau of Economic Research.

Esquivel, G. and F. Larrain. 1998. "Explaining currency crises.” John F. Kennedy Faculty Research WP Series R98-07. June. Available at SSRN: http://ssrn.com/abstract $=107725$ or doi:10.2139/ssrn.107725.

Fano, E. 2001. "H.P. Minsky's reading of the Great Depression." In R. Bellofiore and P. Ferri, eds., Financial Keynesianism and Market Instability. The Economic Legacy of Hyman Minsky, Volume I. Chentelham: Edward Elgar.

Flood, R.P. and P.M. Garber. 1984. "Collapsing exchange-rate regimes: some linear examples.” Journal of International Economics 17 (1-2): pp. 1-13.

Foley, D.K. 2001. "Hyman Minsky and the dilemmas of contemporary economic method." In R. Bellofiore and P. Ferri, eds., Financial Keynesianism and Market Instability. The Economic Legacy of Hyman Minsky, Volume I. Chentelham: Edward Elgar.

Frankel, J.A. 1982. "Flexible exchange rates, prices and the role of 'News': Lessons from the 1970s." In R.A. Batchelor and G.E. Wood, eds., Exchange Rate Policy. London: Macmillan.

Frankel, J.A. and N. Roubini. 2003. [2001]. "The Role of Industrial Country Politics in Emerging Market Crises.” In M. Feldstein, ed., Economic and Financial Crises in Emerging Market Economies. Chicago: University of Chicago Press.

Friedman, M. 1966. [1953]. Essays in Positive Economics. Chicago: The University of Chicago Press.

Keen, S. 1995. "Finance and economic breakdown: modeling Minsky's financial instability hypothesis." Journal of Post Keynesian Economics 17: pp. 607-35.

. 2001. “Minsky's thesis: Keynesian or Marxian?” In R. Bellofiore and P. Ferri, eds., Financial Keynesianism and Market Instability. The Economic Legacy of Hyman Minsky, Volume I. Chentelham: Edward Elgar. 
- 2010. “Are we 'It' Yet?” Steve Keen's Debtwatch. July $3^{\text {rd }}$. http://www.debtdeflation.com/blogs/2010/07/03/are-we-it-yet/, accessed in October 2011.

Keynes, J.M. 1936. The General Theory of Employment, Interest and Money, London: Macmillan.

—. 1937. "The General Theory of Employment." Quarterly Journal of Economics 51: pp. 209-23.

Kaminsky, G.L. and C.M. Reinhart. 1996. "The twin crises: The causes of banking and balance-of-payments problems.” International Finance Discussion Paper No 7. Washington: Board of Governors of the Federal Reserve System. March.

Kaminsky, G.L., S. Lizondo, and C.M. Reinhart. 1998. "Leading indicators of currency crises." IMF Staff Papers 45 (1): pp. 1-48.

Kindleberger, C.P. 1978. Manias, Panic and Crashes - A History of Financial Crises. New York: Basic Books.

Krugman, P. 1979. “A model of balance-of-payments crises.” Journal of Money, Credit, and Banking 11: pp. 311-25.

_. 1996. “Are Currency Crises Self-Fulfilling?” NBER Chapters in NBER Macroeconomics Annual 11: pp. 345-407.

. 1999. "Balance sheets, the transfer problem, and financial crises." International Tax and Public Finance 6 (4): pp. 459-72.

Leijonhuvfud, A. 2009. "Out of the corridor: Keynes and the crisis." Cambridge Journal of Economics 33: pp. 741-57.

McKinnon, R. and H. Pill. 1996. "Credible Liberalizations and International Capital Flows: The 'Overborrowing Syndrome."' NBER Chapters in Financial Deregulation and Integration in East Asia NBER-EASE Volume 5: pp. 7-50.

Minsky, H.P. 1963. “Can 'It' Happen Again?” In D. Carson, ed., Banking and Monetary Studies. Homewood: Irwin, reprinted in Minsky (1982a).

_. 1974. "The modeling of financial instability: An introduction." Modelling and Simulation.

_ 1978. "The Financial Instability Hypothesis: A restatement." Thames Papers on Political Economy.

—. 1981. "The breakdown of the 1960s policy synthesis." Telos: A Quarterly Journal of Radical Thought 50: (Winter 1981-82).

. 1982a. Can 'It' Happen Again? Essays on Instability and Finance. Armonk: Sharpe. 
1982b. "The financial instability hypothesis: capitalist processes and the behavior of the economy." In C.P. Kindleberger and J.P. Laffargue, eds., Financial Crises: Theory, History and Policy. Cambridge: Cambridge University Press.

_. 1983. "The legacy of Keynes.” Metroeconomica 35: pp. 87-103.

1993. "The Financial Instability Hypothesis.” In P. Arestis and M. Sawyer, eds., Handbook of Radical Political Economy. Edward Elgar: Aldershot.

1995. "Longer waves in financial relations: financial factors in the more severe depressions II.” Journal of Economic Issues 29 (1): pp. 83-96.

_. 2008. [1975]. John Maynard Keynes. NY: McGraw-Hill.

—. 2008. [1986]. Stabilizing an Unstable Economy. NY: McGraw-Hill.

Mishkin, F. 1999. "Global financial stability: framework, events, issues.” Journal of Economic Perspectives 13 (Fall): pp. 3-20.

Muñoz, J. and P.N. Snowden. 2006. "Foundering after floating? Exchange rate management and the Mexican stock market, 1995-2001." In L.R. Wray and M. Forstater, eds., Money, Financial Instability and Stabilization Policies. Chentelham: Edward Elgar.

Obstfeld, M. 1994. “The Logic of Currency Crises.” Cahiers Economiques et Monétaires Banque de France 43. [Full article reprinted in L. Sarno and M.P. Taylor, eds., New Developments in Exchange Rate Economics. Chentelham: Edward Elgar. 2002.]

Radelet, S. and J. Sachs. 1998. "The onset of the East Asian Financial Crisis." NBER Working Papers 6680. Washington, DC: National Bureau of Economic Research.

Rietz, T.A. 1988. "The equity risk premium: A solution.” Journal of Monetary Economics 22: pp. 117-31.

Roubini, N. 2011. "Global economic Insecurity and inequality breeds social and political instability." Economic Research, Analysis, Roubini Global Economics, accessed on October 12, 2011, http://www.roubini.com/analysis/164163.php.

Stiglitz, J.E. and C.E. Walsh. 1994. Principles of Macroeconomics. $3^{\text {rd }}$ edition. NY: Norton.

Tornell, A., F. Westermann, and L. Martínez. 2004. "The positive link between financial liberalization, growth, and crises.” NBER Working Papers 10293. Washington, DC: National Bureau of Economic Research.

Variato, A.M. 2001. "Hyman Minsky: what kind of (post-)Keynesian?" In R. Bellofiore and P. Ferri, eds., Financial Keynesianism and Market Instability. The Economic Legacy of Hyman Minsky, Volume I. Chentelham: Edward Elgar.

Wray, L.R. 2009. "The rise and fall of money manager capitalism: a Minskyan approach." Cambridge Journal of Economics 33: pp. 807-28. 


\section{APPENDIX}

Krugman's View of the Crises (Krugman, 1999)

(1') $y=D\left(y, i, e P^{*} / P\right)+N X\left(e P^{*} / P, y\right)$

Where:

$\mathrm{y}=$ national income, $\mathrm{D}=$ aggregate demand, $\mathrm{i}=$ interest rate, $\mathrm{P}^{*}=$ foreign price level, $\mathrm{P}=$ domestic price level, $\mathrm{e}=$ exchange rate, $\mathrm{NX}=$ net exports

Figure 1

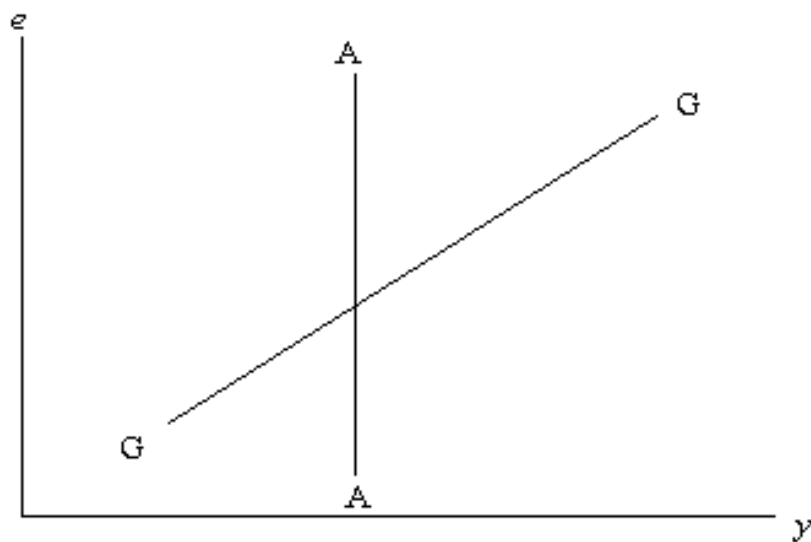


Figure 2

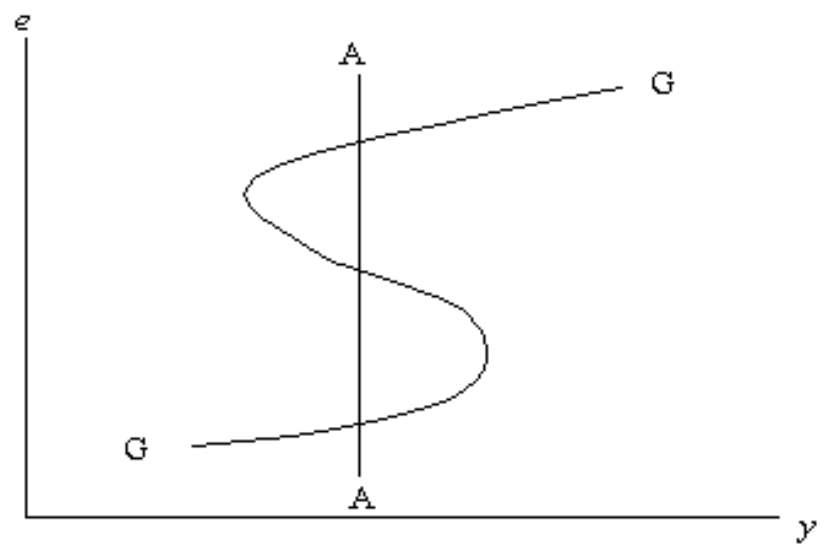

Figure 3

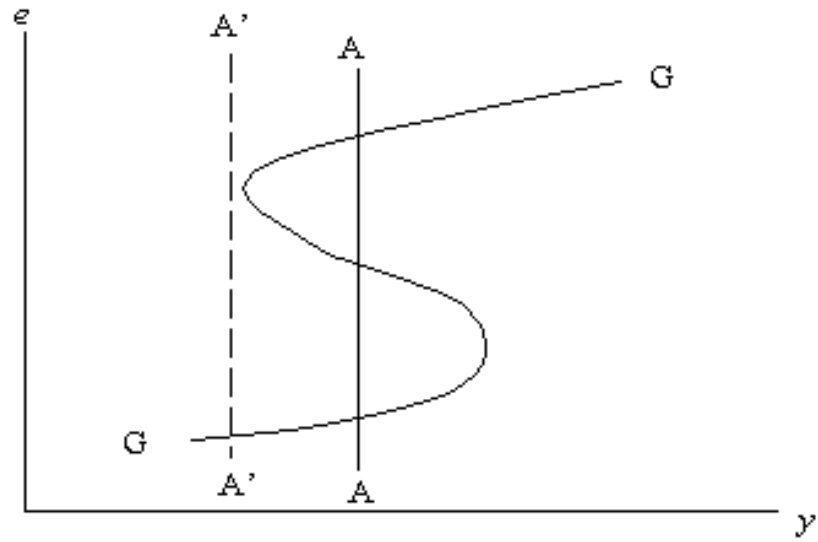

In Figure 3, after an ex post policy measure has been taken, the pressure in the exchange rate has been diminished at the price of reducing income. 